\title{
INTRODUCTION \\ (WITH REFLECTION FROM CHIEF JUSTICE CATHERINE FRASER)
}

\author{
JACK WATSON* \\ Special Issue Coordinator
}

In the century before the creation of the Alberta Supreme Court in 1907 and before the formal emergence of its appeal division in 1914 (which would eventually become the Alberta Court of Appeal), Alberta was a borderless zone, sparsely populated with rough and ready people, not all of whom had particularly amiable views of one another.

Though the laws did not necessarily govern their consciousness, these people were at least artificially governed by English laws as seen through the eyes of local overseers (the Factors), acting for the Governor and Company of Adventurers Trading into Hudson's Bay. Prince Rupert of the Rhine (17 December 1619 - 29 November 1682), a favoured cousin of the "Merry Monarch" Charles II (29 May 1630 - 6 February 1685), received a grant of the Company. The Royal Charter of 1670 gave him "Rupert's Land" which consisted of some 40 percent of modern Canadian territory. ${ }^{1}$ Fortunately history reveals that this was not one of Charles' acts that aligned with the witticism about him that "[he] never said a foolish thing, [n]or ever did a wise one."2

As Justice John W. McClung set out in his valuable and eminently readable Law West of the Bay, the law and its institutions in this vast area were rather a work in progress and of improvisation following the Royal Charter. ${ }^{3}$ That law existed at all was essentially because of the determination of the Hudson's Bay Company to regulate and hold the territory of their trading enterprise. This "outsourced" entrenchment of law underwent a metamorphosis, at least symbolically, with the attempt to formalize English law through the somewhat more regularized Courts of Upper and Lower Canada by the Canada Jurisdiction Act of $1803 .{ }^{4}$ But the Company managed to maintain and even strengthen its governance through much of the nineteenth century (Toronto being an infinite, 1,500 miles off).

But even then the rule of law, howsoever intermittently apparent and obscurely conceived of by its corporate emissaries, with its foundational characteristics still emerging even in England, was settling in. Sir William Blackstone (10 July 1723 - 14 February 1780) was helping see to that, building on the bulwarks established by Sir Edward Coke (1 February 1552 - 3 September 1634) and Sir John Holt (23 December 1642 - 5 March 1710). Combined with the contributions of William Murray, Lord Mansfield (2 March 1705 -

Jack Watson is a "millennial" judge, appointed in 2000 to the Court of Queen's Bench and elevated to the Court of Appeal in 2006. He was also a bemused "witness to history" during 27 years as a Crown Counsel in all levels of Alberta Courts, notably in the Court of Appeal and the Supreme Court of Canada on numberless occasions along with many years of involvement as a lecturer at the University of Alberta, Faculty of Law and scores of other courses and seminars and with various roles for the Canadian Bar Association and Law Society of Alberta.

JW McClung, Law West of the Bay (1997) at 18.

John Wilmot, 2nd Earl of Rochester, "Epitaph on Charles II," online: Bartleby.com < http://www. bartleby.com/40/259.html>.

Supra note 1.

An Act for Extending the Jurisdiction of the Courts of Justice in the Provinces of Lower and Upper Canada, to the Trial and Punishment of Persons Guilty of Crimes and Offences within Certain Parts of North America Adjoining to the Said Provinces, 1803 (UK), 43 Geo 3, c 138. 
20 March 1793), and the prescience, wisdom, and benign rule of William and Mary from 1689 to 1702, keystones in the foundation of the law of Alberta were made.

Although he was referring to a statutory adoption, Justice Jean Côté of the Court (much later copied by the Supreme Court of Canada) wrote that reception of English law permitted the country's common law provinces to adopt a common law system without having to "spend nine centuries painfully building up a system of judge-made law." There was a body of law to absorb through the ordinances of the Northwest Territories and the "made in Alberta" statutes of the still new province when the Alberta Court of Appeal came into being in 1914.

Not long before that year, the Factors' law had been gradually supplanted by a few black robed lawyers-turned-judges and by a dusty line of red coated men who had ridden from the east to battle whiskey dealers and pacify (in the Queen's name) a violent and challenging frontier. They helped regularize what was there before them. But even at that point they represented authority rather than law.

In 1914 what existed was a hodge-podge of both grand and low common law and a ragtag assembly of regulations. The grand principles of the great jurists of history and the Constitution of the new Dominion had yet to be coherently, let alone predictably, associated with the needs and aspirations of the new province and its people. Somebody had to start that massive undertaking, and they had to be credible and honourable in that assignment. Courts were not just to settle horse ownership. Nor were they to maintain surveillance of sewer commissioners like their English ancestors. Through untold decisions, one after another, the Supreme Court Appellate Division (and later the Alberta Court of Appeal) had to weave the fabric of Canadian law and justice for Albertans. They snagged the threads and dropped stitches many times, but weave they did, though their job remains unfinished and the material still needs improvement.

This work was neither easy nor uncontroversial. By definition, Courts are constantly engaged in dealing with disputes, or as our American neighbours call it, "cases and controversies." And the greatest disputant of all is government itself. As pointed out by author David Mittelstadt in Foundations of Justice: Alberta's Historic Courthouses and People Principles Progress: The Alberta Court of Appeal's First Century 1914-2014 both the impartial judiciary and the court buildings in which they came to operate could be regarded as "contentious and controversial" from the point of view of the executive branch of government. ${ }^{7}$ That was particularly so in a province where changes of political control of the executive were infrequent, and yet paroxysmal when they suddenly happened.

Ubi jus, ibi remedium was not an expression born in Alberta, but it was an Alberta Court of Appeal case which firmed it up as the law of the English speaking world: Board v. Board. ${ }^{8}$

JE Côté, "The Reception of English Law" (1977) 15:1 Alta L Rev 29 at 30.

US Const art III, \& 2, cl 1.

David Mittelstadt Foundations of Justice: Alberta's Historic Courthouses (Calgary: University of Calgary Press, 2005) at xvi; David Mittelstadt, People Principles Progress: The Alberta Court of Appeal's First Century 1914-2014 (Calgary: Legal Archives Society of Alberta, 2014) [Mittelstadt, People Principles Progress].

$8 \quad$ Board v Board, [1919] AC 956 (PC). 
This special issue of the Alberta Law Review is complementary to People Principles Progress, which spreads out in colourful detail the many narratives and incidents that comprised the first century of the Alberta Court of Appeal. This special issue contains selected observations about the legal history of the province largely as reflected by vignettes that are not just hagiography.

But this special issue is not just for looking backwards. If all a retrospective did was depict the past, it would not accomplish much - unless it was accurate. We have too often seen, as did our predecessors, that "historicism with integrity" is a rare thing. What of it there is in existence seems continuously under threat by revisionism, idleness, and indifference. A wag once wrote that in the Soviet Union, it was extremely difficult and took much sophistication to predict the past. ${ }^{9}$ But we need to understand how we got here to know where we can choose to go. The past was once the present. Every second of our lives instantly joins the past. The past is meaningful in the now and in the future because it is what we are. With that in mind, we open this special issue with the valedictory by Chief Justice Catherine Fraser at the end of People Principles Progress. We end this introduction with the observations of the Editorial Board, being students of the law yet to embark on their own careers. Providence will hopefully give them the opportunity to reflect further on this in the 100th Anniversary issue of the Alberta Law Review to come in 2063.

\section{THOUGHTS FOR THE FUTURE ${ }^{10}$}

As we celebrate the Alberta Court of Appeal's centennial, this is a time for reflection. Over the past 100 years, the Court has helped shape the province that Alberta is today. At times, it has been characterized as cautious and conservative; at others, as creative and courageous. Sometimes it has had to make unpopular decisions. But at all times, the members of the Court have acted in fidelity to the rule of law and the long-term interests of the province and its people. As the Court's second century begins, I have no doubt that this Court and its members will continue to faithfully protect the values and principles that are the foundations of our free, peaceful and democratic society.

Democracy cannot triumph over tyranny without the rule of law and an independent judiciary. Indeed, without both, there can be no democracy. The rule of law means that no one is above the law including the government. The rule of law is our common consensus, our acquired wisdom, our belief in shared values and our willingness to support and respect one another. Both its strength and its fragility arise from the fact that the rule of law is a belief and an honour system.

Nothing can be built, maintained, improved, used, saved or even spoken about without the shield and voice of the rule of law. It makes everything else possible. However, the rule of law is itself contingent on an independent judiciary able to fulfill its constitutional duty as the third branch of government.

10 Catherine Fraser, Chief Justice of the Alberta Court of Appeal, reproduced with permission from Mittelstadt, People Principles Progress, supra note 7 at 443-44. 
Under the rule of law, citizens have the right to come to an independent court to enforce the law as against government. So too does government against those who might object to its actions. Independent judges have the right to review government actions to determine whether they are in compliance with the law and, where warranted, to declare government action unlawful. And independent judges have the right to review citizens' conduct under the law and, where warranted, to declare the conduct offends the law. These rights are the very assertion of democratic governance.

We are fortunate to live in a country where government recognizes how critical the separation of powers is to our democratic society and in a province in which the Alberta government has provided the resources and funding necessary through the years to support the courts.

The legislative and executive branches of government understand and accept that they will not always be able to do what they want. Sometimes, what they want may not conform to the paramount law, Canada's Constitution. As a general principle, it is the courts that make the final call on the law that binds us all. Government is committed to respecting these decisions in accordance with the rule of law. Otherwise, none of us have anywhere to turn. Most important, it understands that if the public does not have trust and confidence in an independent judiciary, people will not accede to the rule of law. And without the rule of law, all is lost.

There is a legal expression "The law is always speaking." It invites a first question, "To whom is it speaking?" The answer is brief: "Everybody." And that means everybody now and everybody to come. It also invites a second question, "What is it speaking about?" The answer: "Everything." The law constitutes the threads of orderliness in the fabric of our society. As the essential underpinning of our ability to live together, the law touches everything and has always done so.

Citizens may not always recognize what an independent judiciary means to them - until, that is, they run into a problem with, for example, an employer, neighbour, partner, family member, city, police, or government. There are many failed and failing states around the world. What they all share is no rule of law and no independent judiciary. They may have constitutions promising both. But the people in those countries know the promises amount to little, or worse yet, nothing because nothing can be done to enforce them. That is not so in Canada. When there is a conflict to be resolved or constitutional rights to be enforced, we have access to independent courts. However, as with so many things in life, an independent judiciary is something that may not be appreciated until it is gone.

Defending the rule of law is a duty and challenge for the judiciary. We cannot fail. This requires credible knowledge and understanding of both the law and people. If the judiciary is to maintain its integral role in the delivery of justice, we ourselves must meet justice's highest standard. That means an impartial, informed, open-minded judiciary, respectful of change when warranted and resistant to change when capricious. Our citizens expect and deserve no less. 
To those who will be called to serve as judges in the future, the law will also be speaking to you, and in your role, you will be expected to understand it and to explain what it means to the people of your time. In so doing, you will be adjudicators, teachers, and administrators of justice. How you keep yourself informed, how you behave as people and how you carry out your duty as judges are symbolic representations not only of the authority of the law but also of the crucial value of the rule of law. That is why judicial education, particularly on social issues, is so critical. Without knowledge about the real problems of real people and the world around us, it is difficult to understand how one can judge it fairly. This education must continue to be a priority.

You may question what we have said and done, just as we ourselves have sometimes questioned what our predecessors did. But there is one thing that will always endure. That is your role as members of an independent judiciary sworn to protect constitutional rights and adjudicate impartially.

You hold your positions in trust for future generations. The burden you have taken on is foundational. You will need not just intellect and the ability to communicate. You will need courage and fortitude to maintain the rule of law. This ideal is not invulnerable. It is always under threat.

We, your predecessors, inherited the blessings of democracy, freedom, human rights, and the power to maintain these things. This inheritance came at great cost. We did our best to improve the delivery of fair and equal justice and to ensure that all processes of law and government were done fairly and openly. You will do the same. But watch closely. All these blessings and the rule of law can be unravelled the same way they were originally knitted together. The subtle movement of the best of intentions may undermine the rule of law more than the forward rolling of weaponry. We do not need clashes of civilizations, or world wars, to let slip our grasp on the rule of law.

Be vigilant. Be devoted. Be fearless. Remember what you have been entrusted to do. No one else can do it but you.

\section{OVERVIEW OF THE SPECIAL ISSUE}

The subjects covered in this commemorative issue are wide-ranging and varied, reflecting the diversity of issues and interests the Court of Appeal faces. Some of these are more historic in nature but all raise issues and approaches that are relevant to the Court's development today. This diversity is no less reflected in the contributors - judges, practitioners, academics - all of whom interact with the Court in different ways and address their issues through varying lenses. As the highest Court in the province, the Alberta Court of Appeal deals with both the fundamental principles of law, and evolving social values and concerns, on a wide variety of topics. The range of perspectives reflects these topics and concerns.

We start with articles from three Justices of the Court of Appeal, all of which address historic developments and legal changes in a way that is still highly relevant. Justice Watson's analysis of the rule of law and judicial review provides a detailed historic overview 
of an early case, dealing with the seemingly simple sale of twelve bottles of whiskey in Edmonton, but ending all the way at the Privy Council. In doing so, it also discusses the development of the law of certiorari from its British roots, up to its modern implementation in Canada. This is followed by a reprint of the late Justice Morrow's article detailing his involvement with the last Canadian appeal to be heard by the Privy Council in England. This provides an engaging behind-the-scenes view of a bygone aspect of our legal system. Following this is Justice Côté's history of the factum, the ever relevant and essential tool in any lawyer's kit.

After this follow articles which look at the Court (historically and more recently) and its work grappling with historic and contemporary issues and social concerns. Graham Price's overview of life in the criminal courts of the Northwest Territories addresses some of the practical historical issues facing the Court, including the Court's engagement with Aboriginals. Robert Normey's article also investigates Aboriginal litigation in Alberta's Court of Appeal over the last 100 years, and engages with the effects and changes wrought by the Charter. ${ }^{11}$ The Charter, in turn, is the subject of P. Jonathan Fauld's article on the contributions made by the Alberta Court of Appeal to early Charter interpretations. The Court's interaction with evolving social values and views is discussed in Janine Benedet's article on the well-known Ewanchuk case ${ }^{12}$ and the Court's evolving attitudes towards sexual assault.

After this comes Justice Côté and D.J. MacGregor's article on the continued importance of legal research, a subject that will always be of relevance to the Court of Appeal and legal practitioners before it. This is followed by Laura Hoyano's illumination of the Court of Appeal of England and Wales (Criminal Division) as compared and contrasted to the Alberta Court of Appeal. This Court is only slightly older than Alberta's Court of Appeal and each Court has moved into the modern era still imbued with its respective sense of history and its inclination to maintain inherited traditions

From these articles, the special issue then moves to two case comments on more contemporary issues that have just recently been before the Court. The first by Roderick J. Wood addresses the Court of Appeal's contributions to the development of the small but fundamental field of common law bankruptcy law. Bruce Curran's case comment addresses Alberta's privacy legislation and the recent decision by the Supreme Court of Canada affirming the Court of Appeal.

The issue, finally, and fittingly, concludes with Wayne Renke's enthusiastic book review of David Mittelstadt's People Principles Progress, a history of the Court of Appeal's first one hundred years. As Renke states, all Alberta lawyers should read this book. While this special issue provides numerous vignettes of the Court of Appeal's history, Mittelstadt's book provides a detailed overview of the entire history of the Court. It is thus the final bird'seye view of the Court's history and draws out powerful themes of its continued contribution to the rule of law. 


\section{REFLECTION OF THE ALBERTA LAW REVIEW EDITORIAL BOARD ${ }^{13}$}

In many ways, law is a process of looking to the past in order to gauge the future. This process might not always be tidy and might not always tend in the direction we want but the law is based on precedent. To understand precedent we must, ideally, look to our history, both to appreciate what has been done and to continue to strive to improve and correct any mistakes that have been made. However nothing exists in a vacuum, and legal judgments interact with society and its values, often in complicated ways. As do people, principles, and progress, the law, hopefully, moves with them. It may react or inspire reaction, but the law can be a signal of what is coming or what needs to come. And as future lawyers, we look to written judgments perhaps more than anything else as a way to learn to navigate this world.

For students, there is perhaps nothing more frustrating or intriguing as the attempt to understand the judicial mind. It is at once completely foreign (at least in first-year) and completely essential to our success as students and eventual lawyers. As the court of highest appeal in our province, the Alberta Court of Appeal occupies one of the most central positions in students' minds and in many of our courses. The Court offers direction and correction on a myriad of legal topics and, while not the highest court of the land, it is more directly and immediately relevant in our day-to-day lives. Also, as this issue demonstrates, the Court of Appeal is often (though not always) close in reasoning with the Supreme Court of Canada. As such, the Court can be a source of wisdom and clarity, but it can also be a source of confusion.

It can be easy sometimes to look back in time and think that a particular judgment is clearly and obviously correct (or perhaps clearly not), but without a grounding as to why and how that particular decision was reached, we may be missing critical analytical factors. These factors will, in turn, become relevant to law students after we graduate and as we progress in our careers, hoping to make a difference and use the law to its fullest potential. As the saying goes, those who fail to learn from history are doomed to repeat it. In our common law system, the Court of Appeal literally makes law (or, as is sometimes said about the common law system, reveals the law), and a failure to understand the Court properly will be a failure to understand the law properly.

The articles in this issue offer a glimpse into the heart and mind of our Court of Appeal. They offer not just judgments as they appear in law reporters, but the stories, ideas, and values behind some of those judgments. These in turn show glimpses into the minds of the men and women behind the Court. Therefore, creating this issue has been as illuminating as it has been educational: shedding light behind the black letters and white pages of the law. What it has revealed is a Court that, far more often than not, instills confidence and respect.

The Court has frequently been called on to address particularly contemporary moments - moments when the law may not have always kept pace with societal concerns. It is not an enviable job, but the Court has continued to rise to the challenge. The Court has been called upon to enforce civil rights, to curtail government powers, and to define values central

13 The Editorial Board would like to thank Elsbeth Cochrane for her assistance in drafting this reflection on its behalf. 
to Canadians. Although the luxury of hindsight allows us to debate how correct any one judgment is, looking through the lens of history reveals that none can be said to be entirely wrong. The rule of law still reigns, and our society thrives as a result. As the future members of the legal profession, we can look forward with hope and confidence that, under the watchful eye of the Alberta Court of Appeal, it shall continue to do so for another hundred years. 